\title{
Indian Anuvād or English Translation? Combining Tradition and Modernity in the Nationalistic Translations of Nineteenth Century Bengal
}

SASWATI SAHA

\begin{abstract}
Translation is a space where two cultures encounter. Yet a detailed study of the translation practice prevailing in colonial Bengal and the etymology of the various words used in the Indian context to denote the practice reveals an interesting scenario where translation and its methods created a fertile but disquieting space where two cultures encountered and created a sphere in which one both abandons and assumes association. This research paper will deal mainly with the question of translation as it is conceived in the European epistemology and its effects on the indigenous understanding and practice of anuva $\bar{d}$ in the nineteenth-century Bengal. The difference between the signifier (translation) and the signified $($ anuvād) created as a result of the gap in the understanding of the practice in the two different cultures leads to confusion among the native translators who are caught up in the middle of two very different practices. Through a study of Vidyasagar's translations from Sanskrit to Bengali this paper would show how the Indian pandit strives to keep association with the indigenous practice of anuvād and yet finds it difficult to come out of the European understanding of it. This paper will focus on how combining the two practices of translation the Bengali intellectual constructed a modern identity of the Indian self that neither complied with the West, nor with the East; rather attempted to attack the binaries of the Western-Eastern, rationality-spiritualism, translation-anuvād and created a third space which could
\end{abstract}


combine the two in order to give rise to a higher form of nationalism.

Keywords: Translation, Anuvād, Culture, Epistemology, Third-space.

India being a multi-lingual nation, the idea of translation is not new. But 'translation' as we know it today through our knowledge and correspondence with European epistemology was unknown in pre-modern India. In ancient times Sanskrit texts were freely rendered into Prakrit and the term used for such conversions was chājia , i.e., shadow. In other words, the converted text would be the shadow of the 'original'. In fact, the concept of the 'original' hardly existed in the pre-modern Indian translations. With the rise and popularization of the vernaculars, the smrti texts like the Ramajyan and the Mahäbhärat were composed in the regional languages. Although these texts were largely based on the Sanskrit texts of Valmiki and Vyasa, they were considered as original works in their own right. Krittibas's Rāmāyan in Bengali, Tulsidas's Rāmcaritamānas in Hindi, Kamban's Rāmāyan in Tamil were regarded as no less than originally composed texts. But the question is why these later versions which resemble the Sanskrit text in the larger plot, dramatis personae, theme, and most of the anecdotes are not called 'translations'? The answer to this can be, as Harish Trivedi argues, that "this question is so western that an Indian will never raise it". (Hermans 2006: 107) Therefore an understanding of the concept of translation in the Indian paradigm becomes essential before proceeding further.

\section{Ancient India: Translation as Anuvād}

The Sanskrit terms and theories were produced so early that finding English equivalents for them pose a problem. Moreover, the meanings that those terms conveyed to the scholars in those days are in no way similar to the way we use 
them today. Words evolve over a period of time and acquire new meanings according to the changing need of the society. The way we use the word "anuva $d$ " today is almost equivalent to the English word "translation", but it is actually a much later usage. Etymologically the word anuvād actually meant "repetition of something that has already been said" (kathita bisayjer punah kathan, punarukti). An entry in the Bangiya Śabda Koś says that one understanding of translation is "anukșan kathan, anukirtan" which means orally repeating something, chanting constantly. An ancient śloka states "likhita granther yadi kari anubād/ tabe se granther artha pāiye a asvād". This means anuvād only meant oral repetition of something that has already been stated and written down and that this practice provided a better understanding for anyone who may not have heard it right or grasped it adequately for the first time. Moreover, the idea of anuva $d$ in the pre-modern times was completely oral and had no relation with re-writing or re-stating. That anuvād means a repetition in a language other than that it was originally composed (bhāsāantarer mädhyame punahkathan) came into existence much later in the $19^{\text {th }}$ century when the Indians had to look for a word that would carry essence of the term "translation" as it was used by the colonizers. ${ }^{1}$

The idea of authenticity was compromised in ancient Indian tradition of translation. The concept of loss and gain through translation was not really a cause of anxiety in pre-modern translations in India since it was considered a case of repetition or bringing to the mass the texts that they cannot approach directly because of their ignorance in that particular language. The anxiety of betrayal associated with translation never seems

See the gradual evolution of the word anubād in Haricharan Bandyopadhyay, Bangiya Śabda Koś (Calcutta:Sahitya Akademi, 1932) for a detailed etymological understanding on the term 
to have existed in the past. Harish Trivedi, in a discussion on translation practices existing in ancient India points out that the concept of loss that scholars think is incurred due to the lack of "fluency" never existed is clear from what Tulsidas writes in the preface of his Rämāyan in Hindi. Tulsidas unhesitatingly declares:

As is in accordance with the various puranas, nigamas and agamas,

And as narrated in the Rāmāyan, with something from elsewhere too,

Tulsi enlarged on the story of Ram, for his own pleasure,

In soft and attractive diction and composition (Hermans 2006: 107).

The poet admits the fact that that he has composed a new text of Ram "for his own pleasure", "enlarging" the story of Rämāyan. The word "enlarged" in this context might mean extending the text to those who have no access to the Sanskrit texts, and also the inclusion of various tales that he has juxtaposed from "elsewhere". Thus, in these translations, "the verbal transference carries its own disjunctive function, makes the translation something other than the original, reveals in the original the potential to be something other than itself." (Chaudhuri 1999: 3) Departing from the "original", and innovating new tales, it redefines the "original", focusing on its various possibilities. The pre-modern translator neither suffers from Bloom's "anxiety of influence" nor Derridean différance of "endlessly differing the implication of the original". Again, there exists no carrying over from one culture to another in case of Sanskrit to the vernacular language; the translator had no pressure of "respecting difference". Here the reader and the text are not separated by culture but by time. The translator endeavours to pick the classical text and bring it to the readers 
who would otherwise remain ignorant of their rich cultural heritage.

\section{The Coloniser's Project: Orientalists and Their View on Translation}

The advent of the British colonisers brought in the practice of translation with new aspects associated with the European paradigm. Their desire of knowing their subjects, their past history which they thought would facilitate their rule, urged them to collect ancient Sanskrit texts and translate them for "all who hold office in India, whether in the Civil Service or in any other capacity." The difference in the methodology between those translation practices existing in India prior to the British rule and the ones that the colonisers practiced were considerably different. Since the "Orientalist" project was that of presenting one culture to another, the translated works of Nathaniel Halhed, Charles Wilkins, William Jones and Monier-Williams had to shoulder a certain responsibility of being faithful to their readers. Hence, they aimed at literal translation from the ancient scriptures and added annotations wherever necessary to explain to their readers a culture that might seem completely alien to them. Charles Wilkins, in the preface of his translation of Hitopadeś writes in 1781:

The following translation, begun and completed this summer during a temporary residence at Bath, is a faithful portrait of a beautiful work, which in the opinion of many learned men, Natives and Europeans, with whom I had the honour to converse upon the subject before I left Bengal, is the Sanskreet original of those celebrated fables, which after passing through most of the oriental languages, ancient and modern, with various alterations to accommodate them to the taste and genius of those for whose benefits and amusement they were designed, and under different appellations, at length 
were introduced to the knowledge of the European world with a title importing them to have been originally written by Pilpay or Bidpai, an ancient Brahman, two names of which, as far as my enquiries have extended, the Brahmans of the present times are totally ignorant [my emphasis] (Wilkins 1787: 1).

Here the translator not only shoulders the responsibility of presenting the authentic text to his readers, but also render it "faithfully" without any alterations what so ever. This idea of the authentic text was unknown to the Indians so far. This idea of rendering the translator completely invisible and giving the readers a direct access to the 'original' text written by the author was new to this country.

The question of authenticity weighed heavily on the Orientalists and a study of the prefaces to their works proves the anxiety that they experienced. William Jones, in the preface of his translations of the Poems from the Asiatik Languages, writes, "The readers will probably expect, that, before I present him with the following miscellany, I should give some account of the pieces contained in it; and should prove the authenticity of those Eastern originals, from which I profess to have translated them..." 2 Thus providing a brief history of the work and how the translator has actually come across it becomes essential to prove that he has actually taken up the proper/real text and hence is presenting the truest version so that his endeavours might not be suspected. His effort of translating the "most universally esteemed Indian

\footnotetext{
${ }^{2}$ William Jones, "Poems consisting chiefly of Translations from the Asiatik Languages", Collected works of Sir William Jones. (London: MDCCXCIX). Jones' detailed preface for all his translated works provide an insight to the source text used by him and the methodology followed by him.
} 
Nātaka", "Calidas' Sacoontala" also bears the proof of his anxiety for authenticity. He writes:

I then turned it word for word into English; and afterwards, without adding or suppressing any material sentence, disengage it from the stiffness of a foreign idiom and prepared the faithful translation of the Indian drama, which I now present to the public as a most pleasing and authentic picture of old Hindu manners, and one of the greatest curiosities that the literature of Asia has yet brought to light (Pachori 1993).

But the idea of translation in the European episteme brought down by the European Colonizers is not a homogenous idea and is fraught with dissentions. The great debate over wordfor-word translation and sense-for-sense translation continued as late as the second half of the $20^{\text {th }}$ century. The major problematic was experienced in the case of Bible translation which was the "Word of God" and therefore cannot be tampered with. Any small diversion would amount to heresy and could lead to dire consequences. Still experiment continued from Cicero to St. Jerome to Martin Luther, where at one point one decides to be an interpreter (giving a wordfor-word translation), whereas some decides to be an orator (providing a sense for sense translation). But throughout the $17^{\text {th }}, 18^{\text {th }}$ and $19^{\text {th }}$ century all the theorists including Dryden, Tytler and Schleiermacher stressed on the complete understanding of the original text, its style and manner of writing. This is necessary since a lot of invention on the part of the translator makes him visible.

\section{Translation in Early Modern India: A Tale of Reception and Rejection}

Placing Vidyasagar's translation practices in the light of all these conflicting tradition of translation shows how translation in early modern India was a tale of reception and rejection of 
the western paradigm. It also helps in understanding how Western method of translation, which came with an aura of superiority, gradually got infused and informed the Indian practice of translation of not just from English to the vernaculars but also from Sanskrit to the native mother-tongue. When Vidyasagar, the major educationist of the period, was translating from Sanskrit into Bengali to compose text books for the students of the vernacular medium, he was carrying the legacy of not just the ancient Indian understanding of the practice of anuvād because he was a Sanskrit pandit himself, but his knowledge of translation was also informed by the western understanding of translation that was largely prevailing all around him. The question therefore is how did the Sanskrit pandit whose tradition was so accustomed with the practice of collation and recreation untangle the semantics of translation and anuvād?

Of course, Vidyasagar was not the first among the indigenous population to have taken up translation. But the point when he stepped into the scene was interesting since it was when the Indian intellectuals were still grappling between the ancient and modern methods of translation. His translation works from Sanskrit to Bengali includes Rjupāth (1851), Sakuntalā (1854), Bidhabā Bibāha Pracalita haoȳa Ucit kinā etadbișaýak Prastāb (1855), Mahābhārat (1860), Sìtar Banabās (1860). In order to examine Vidyasagar's work in the light of the practice prevailing then in Bengal, we will have to consider the methodology he followed, the group of people whom he considered to be his targeted readers and the reason behind his translations. Since Vidyasagar's main aim was that of preparing text books for the students of the vernacular schools, all the books mentioned above, except Bidhaba Bibāha, are meant to be read by children of 7-12 years. A study of two types of translation would reveal that the methodology changes according to the mission and hence the 
translator switches between the pre-modern and modern idea of translation according to his necessity.

In his preface to Mahābhärat, Vidyasagar admits that both he and the Tattvabodhinī Sabhā, for whom he ventured to translate, wanted to present "abikal anubād" (literal translation) of the text. He says that he tried his level best to provide his readers with the authentic version but translation of the epic is not an easy job. There are many places in the original text that are ambiguous, and cannot be easily interpreted. But he has endeavoured to comprehend them through the various commentaries $(t i k \bar{a})$ and has translated only after thorough understanding. But he is well aware of the fact that this might lead to contradictions among people who might interpret those sections differently. He points out in the preface:

The intention of the Tattvabodhini Sabhā was to literally translate the original text and even I tried so while translating... There are many places in the original text which are ambiguous and hence difficult to come across the real meaning. For those places I have carefully studied the commentaries and descriptions available and have translated accordingly. Therefore, not all may agree with those sections. Hence for various such reasons the translation of Mahābhārat is not an easy job. (My translation $)^{3}$

The translator here is well aware of the various opinions that exist regarding the interpretation of the epics in India. But strangely enough he considers the epic a singular text which, according to him, is the original and he wants his version to resemble it in the closest possible way. Rjupāth Dvitīya bhāg is

3 Vigñāpan of Mahābhārat by Vidyasagar in Suniti Kumar Chattopadhyay, Brajendranath Bandyopadhyay and Rajanikanta Das(ed), Vidyāsāgar Granthābali Sāhitya (Kolkata: Ranjan Publishing House,1937). 
a collection of tales from Rāmāyan and here too he acknowledges it too be a single text created by Valmiki. He says in the preface:

Rjupāth Dvitīya bhāg has been collected from the Rāmāyan. The style of composition tells that Ramayana is an ancient text. This ancient text is known to have been composed by Maharshi Valmiki ${ }^{4}$ (my translation).

But Vidyasagar, being a Sanskrit Pandit himself, was well aware of the fact that texts in India remained scattered in various places and "translation" practice constituted of collating those texts and then giving them a new shape, which often differed from the "original" in quality. He himself had edited various Sanskrit texts after collecting their parts from various parts of the country. Meghdütam, for instance was printed after collating four texts from Calcutta, Varanasi and other parts of India with the interpretation and analysis of various commentators. (Chattopadhyay et al 1937: 4) In the preface to his edited version of Uttarcarit, he acknowledges the fact that the various versions of the text that he procured from Calcutta, Varanasi and Vijayanagar were very different in their renditions. He had to study them very carefully and render the version as close to the 'original' that seemed most convincing to him. Moreover, he did not forget to show the differences that exist between the various versions. (Chattopadhyay et al 1937: 5) He also edited Avigñanam Śakuntalām as Calcutta University had decided to teach its students the version that was popular in the north-western parts of India whereas the version that already existed in Calcutta was that of the Gour region. The two texts, according to

\footnotetext{
4 Vigñapan of Rjupāth Dvitī̇ya bhāg by Vidyasagar in Suniti Kr. Chattopadhyay, Brajendranath Bandyopadhyay and Rajanikanta Das (ed), Vidyāsāgar Granthāvali (Śikșā o Bibidha). (Kolkata: Ranjan Publishing House, Phalgun,1937)
} 
Vidyasagar were very different from each other. He therefore had to set out on a journey to Varanasi in order to collect the required texts. He was lucky enough to have found five different ' $m \bar{u} l$ ' or original texts which he used in editing this new text (Chattopadhyay et al 1937: 4).

From among his edited texts, he wrote two famous textbooks: Śakuntalā, from Avigñanam Śakuntalām in 1854 and Seetar Banabash, from Uttarcarit in 1860. In case of Sìtār Banabās, he composed the text combining Bhababhuti's Uttarcarit and Uttarkānd of Rämājan. But he could not present the text literally as they were and had to purge certain sections since the book was meant for the student. But these changes were not made comfortably. The translator constantly remains anxious of the fact that his readers might not derive the same pleasure as word-for-word translation would have provided (Chattopadhyay et al 1937: 5). In the preface to Śakuntalä, he writes that his attempt is to provide those people who are ignorant of Sanskrit an essence of India's best Nātak. But he grieves and apologizes for the fact that he could not provide them with all the literary wonders that are present in the original. In the preface he writes:

Those who have read Avigñanam Śakuntalām, and will read these renditions, will easily find out the difference in the wonders of the two texts, and will admonish me in their mind several times for presenting this version to the people who have no knowledge of Sanskrit. In fact, I have actually shown much disrespect to both Kalidas and Avigñanam Śakuntalām by compiling it in Bengali (my translation) (Chattopadhyay et al 1937: 4).

Vidyasagar's imperative for these translations was multifaceted. He was of course an educationist who strived for the improvement of the mother-tongue and wanted to provide his students with easy access to the classical texts that could 
infuse in them a pride for their rich cultural heritage. But one must not forget that he was also a social reformer. An analysis of his book Bidhabā Bibāha (a proposal on widow remarriage) would reveal how his translation practice changes when he assumes the role of a reformer and address his work to people who constitute the adult population of Bengal. Brian Hatcher in his work on Vidyasagar's translation of Bidhaba Bibāha (a proposal on widow remarriage) has focused on Vidyasagar's role as a translator where he endeavours to carry the meaning of Hindu religious life across distances of time, practice, or community. The reformer did not choose an obscure text, rather he used texts that were widely prevalent but he used his genius in translating that corpus of knowledge into meaningful terms for Bengali students and intelligentsia and thus applied them successfully to meet his own ends. In an attempt to domesticate ancient Sanskrit texts, the reformer attains the status more of a revivalist. Thus when Vidyasagar cites a minor argument from the Vedic texts against bidhaba bibāha, he is actually using it as a weapon against a major discourse prevalent in the society to subvert and frustrate it by revealing the presence of the new discourse in the scriptures and hence ratified by the wise sages. ${ }^{5}$ Here he insists on literal translations of the ancient texts since his goal is to convince the public to endorse his proposal regarding the śāstric validity of widow remarriage. He rests his argument on the weakness of the Hindus about the ancient scripture and he is well aware that no Hindu will be able to refute anything that is written in the Śástras. He says in the introduction to book one:

In this land the authoritative treatises are the ultimate valid authority in all such matters. Everyone accepts that

${ }^{5}$ See Brian Hatcher, Hindu Widow Marriage: An Epochal Work on Social Reform from Colonial India (New York: Columbia University Press, 2011) for further discussion. 
actions in agreement with the authoritative treatises are required sacred performances. Therefore, we must begin by determining whether or not widow marriage is in accord with the authoritative treatises. ${ }^{6}$

In his Bidhabā Bibāha, Vidyasagar never uses the word anuvad, rather the words used are "communicating", "explaining". He writes in the preface of Book Two:

Majority of my readers do not know Sanskrit. I choose to write the meaning of the Sanskrit passages in the vernacular so that they may understand. Since my readers depend upon a vernacular explanation, it is absolutely necessary to provide a reliable explanation in every instance. No respectable person would provide a dubious explanation in order to mislead people.

Here the translator Vidyasagar seeks a faithful rendition of the ancient scriptures for his ignorant readers and he thinks it is his responsibility to be true to them about the explanation of the text and that a deviation would amount to cheating his readers. Hatcher has regarded Vidyasagar as more of a commentator in this case than a translator since "he seeks to explain, restate, interpret, and ultimately offer the most authoritative explication of the Sanskrit source material." 8 Vidyasagar's repeated use of the word "arthāt", which means 'in other words' gives him the status of a Sanskrit commentator, who is stating something that has already been stated.

\footnotetext{
${ }^{6}$ This is a quotation from Brian Hatcher's translation in his unpublished work "Writing Sanskrit in the Vernacular: The Semantics and Practice of Translation in Early Colonial Bengal".

7 This is a quotation from Brian Hatcher's translation from his unpublished work "Writing Sanskrit in the Vernacular: The Semantics and Practice of Translation in Early Colonial Bengal".

${ }^{8}$ Brian Hatcher, "Writing Sanskrit in the Vernacular: The Semantics and Practice of Translation in Early Colonial Bengal", Unpublished work.
} 
The coming in contact with the European paradigm and understanding of translation had a major impact on the understanding of anuvād in India. The relationship between the signifier and the signified undergoes a major change. Meaning for the English was something attributed to a word, a phrase, or an object, which could be determined and translated, at best with a synonym that had a direct referent to something in what the English thought of as a "natural" world. Everything had a more or less specific referent for the English. With the Indians, meaning was not necessarily constructed in the same fashion. (Cohn 1997: 18-19) What was previously understood by anuvād did not anymore correspond to the practice in the $19^{\text {th }}$ century. The difficulty that the Indians faced while practicing translation in the $19^{\text {th }}$ century is evident from the fact that they could not even decide upon a proper word that could define their activity. The term that was by and large accepted was anuvād but as I have discussed above the term brought with it a baggage that had connotations remarkably different from what the $19^{\text {th }}$ century translators were doing. The choice of the term was interesting in the sense that it "encouraged the belief that the practice is as old as the word" and the shift in the meaning "is indeed symptomatic as any evidence one could adduce of the wide gap between the Indian literary practice and the Western." (Hermans 2006: 110) But nonetheless the modern usage of the term is just a semantic neologism invented to cope with the English understanding of the term 'translation'. The other Indian words used to denote this new practice of translation are bhāṣāntar, rūpāntar, turjumā but these are words are by no means synonymous and carry a set of meanings of their own providing a whole new understanding of the practice.

Since translations are not made in a vacuum and translators' function in a given culture at a given time, the way they understand themselves and their culture in one of the factors 
that may influence the way in which they translate. The various connotations of the word translation that came to be used in the Indian vernacular were effectively used and deployed by the translators according to their own politics of translation. In the case of Vidyasagar, the anxiety about literal translation while translating from Sanskrit into Bengali was an attempt of bringing "our own glorious tradition" to those ignorant people who have no access to Sanskrit. This required him to be ethical enough as a translator to make his rendition appear a mere repetition of the "original" text. Here he desires to hide his identity as a translator and wants to provide his readers an easy and unhindered access to a text of unrivalled excellence. But his angst about the authenticity is an acquired affect of the Western understanding of translation, a concept brought down by the British. The overwhelming presence of the Western literature created a fear in the minds of the indigenous population that it might obliterate those differences which marks the national culture as something distinct from the western culture. Thus, there was a conscious effort to stick to one's own tradition with an aim of upholding its certain aspects to establish its superiority.

The constant preoccupation with the authenticity and the pain experienced as a result of the failure of attaining it can also be tied up with imagined nation of modern India. Jacob Golomb in his work In Search of Authenticity attempts to read authenticity as an integral part of Western philosophical, humanistic traditions. Authenticity, Golomb noted is bound to notions of authority: 'One is historically authentic when one creates one's own history by utilizing and recreating one's past and the past of one's people, projecting them with anticipatory resoluteness towards one's future... (Authenticity) is the loyalty of one's own self to its past, heritage and ethos.'(Chaudhuri 2006: 261) This is often seen as an attempt of upholding the culture of a colonized country which the 
colonizer has declared "inauthentic" and has therefore tried to repair in their own "benevolent" way. The internalization of the idea of the superiority of the white race gives rise to a vicious self-denigration among reactive cultural nationalists in the latter half of the century and therefore an attachment to the authentic Bengali roots is essential. To repair the damaged self-esteem created by the colonized rule and the introduction of the Western education, a concerted effort was made by the prominent Bengalis to use their own tradition as a weapon to survive under the colonial political economy and to preserve their prestige.

\section{Conclusion}

In his attempt of rendering the translations faithfully in Bidhaba Bibāha, Vidyasagar is actually reviving the ancient texts to use them as weapons to frustrate and subvert the discourse prevailing in the society. Then he uses this translated text to translate the society. In this case he is foreignising because he has to retain the difference between the prevalent discourse and the discourse that he has brought forward. Here the "breach" is important since it is the only way through which he can show the flaws of the existing society and establish his point. His success depends on the acceptance of argument which is only possible when the idioms of his discourse will become a part of the target language's extended vocabulary. Fluency in this case might lead to the forgetting of the alien aspect of what has been translated. But it has to be remembered in this process the translated discourse might wipe out other minor discourses which are very much a part of the society. However, in case of the textbooks there exists an anxiety of providing the most faithful representation of the unparalleled texts ever composed in ancient India to the students at a very early stage cannot be without some special aim. While translating from English into Bengali Vidyasagar's 
emphasis is on the imitation. He never strives for equivalence, since he is perfectly aware of the impossibility. In almost all his prefaces he mentions clearly that these texts are not "abikal anubād" (literal translation). He acknowledges in the preface of Jỉban Carit that literal translation from English to Bengali is extremely difficult due to the difference in the linguistic styles and attempting it might eventually lead to the mistranslation of the actual meaning. He makes desired additions and alteration in order to simplify the texts for the students. But when he is translating from Sanskrit into Bengali for the composition of textbooks, there is no question of domesticating the original text. He is careful not to make any alteration, except omitting certain sensual sections, which he thinks are inappropriate for the young students to be studied in classrooms. Therefore, there is a significant difference in the translation strategy according to his role as a social reformer and an educationist. But in both the cases he is not bothered about the linguistic impossibilities. One of Vidyasagar's aims was definitely to improve the vernacular by both associating and distancing it from Sanskrit, the parent language. Moreover, the idea of literally translating from Sanskrit did not appear completely impossible to him perhaps because of the fact that he might have thought that there exists certain linguistic similarity between the two languages, since one is derived from the other, which makes the exact rendition possible.

\section{References}

BANDYOPADHYAY, HARICHARAN. 1932. Bangiỹa Śabda Koś. Calcutta: Sahitya Akademi.

CHATTOPADHYAY, SUNITI KR., BRAJENDRANATH BANDYOPADHYAY AND SAJANIKANT DAS. (eds.). 1937. Vidyāsāgar Granthāvali (Śikṣā o Bibidha). Calcutta: Ranjan Publishing House. 
CHATTOPADHYAY, SUNITI KR., BRAJENDRANATH BANDYOPADHYAY AND SAJANIKANT DAS. (eds.). 1937. Vidyāsāgar Granthāvali (Sāhitya). Calcutta: Ranjan Publishing House.

CHATTOPADHYAY, SUNITI KR., BRAJENDRANATH BANDYOPADHYAY AND SAJANIKANT DAS. (eds.). 1937. Vidyāsāgar Granthāvali (Samāj). Calcutta: Ranjan Publishing House.

Chaudhuri, Rosinka. 2006. Cutlets or Fish Curry?: Debating Indian Authenticity in Late Nineteenth-Century Begal. Modern Asian Studies 40.2.

Chaudhuri, SuKanta. 1999. Translation and Understanding. New Delhi: Oxford University Press.

COHN, BERNARD. 1997. Colonialism and its Forms of Knowledge: The British in India. New Delhi: Oxford University Press.

HATCHER, BRIAN. 2011. Hindu Widow Marriage: An Epochal Work on Social Reform from Colonial India. New York: Columbia University Press.

Jones, WILliam. MDCCXCIX. Collected Works of Sir William Jones. London.

PACHORI, SATYA S. (ed.). 1993. Sir William Jones. New Delhi: Oxford University Publications.

TRIVEDI, HARISH. 2006. "In our own Times, On our own Terms". In Theo Hermans (ed.), Translating Others 1. Manchester: St. Jerome Publishing. WiLKINS, CHARLES. (trans.). 1787. Heetopodesha of Veeshnoo Sarma in a Series of Connected Fables Interspersed with Morals, Prudential and Political Maxims. Bath. 